\title{
IF THE QUEEN WERE TO ABDICATE: PROCEDURE UNDER CANADA'S CONSTITUTION*
}

\author{
MARGARET A. BANKS**
}

\begin{abstract}
The author looks at the legal aspects of the question of how Queen Elizabeth II could successfully abdicate the throne in order to allow the Prince of Wales to become the King of Canada as well as the King of the United Kingdom. Particular attention is given to the issues of which measures Canada would have to adopt to allow the abdication, how these measures would have to be enacted, and which level of government in Canada would have constitutional jurisdiction to enact them.
\end{abstract}

L'auteur se demande comment, sur le plan juridique, la Reine Elisabeth II pourrait abdiquer de façon à permettre au Prince de Galles de devenir d la fois Roi du Canada et Roi du Royaume-Uni. Elle examine tout particulièrement quelles mesures le Canada devrait adopter pour permettre l'abdication, comment il faudrait les décréter et quel niveau de gouvernement canadien aurait la compétence constitutionnelle requise.

Every now and again the suggestion is made that Queen Elizabeth II should some day abdicate in order to allow the Prince of Wales to become king before he is an old man. An opinion poll in Britain late in 1988 indicated that fifty-nine per cent of those questioned thought the Queen should take this step.' That she will do so seems to me neither likely nor desirable. There is no precedent in British history for such a course, though Queen Victoria sometimes threatened to abdicate when she was displeased with her ministers. ${ }^{2}$ As is well known, King Edward VIII's abdication in 1936 was for a different reason, unrelated to the present situation. In case the Queen should decide to abdicate at some future date, it is well to determine how the accession of a new monarch under these circumstances would be accomplished in Canada.

W.P.M. Kennedy outlined very clearly in the second edition of his book The Constitution of Canada the procedure adopted with regard to the abdication of Edward VIII. ${ }^{3}$ Briefly it was as follows.

Section 4 of the Statute of Westminster, 1931, provided that no Act of the United Kingdom Parliament should henceforth extend to a Dominion as part of its law unless it was expressly stated in the Act that that Dominion had requested and consented to the enactment. ${ }^{4}$ The King executed an instrument of abdication on December 10, 1936. Although his right to abdicate had never been in doubt,

* The author is grateful to Professor Peter W. Hogg, Osgoode Hall Law School of York University, for reading a draft of this paper and making helpful suggestions that have now been incorporated into the text.

** Margaret A. Banks, Professor Emeritus and former Librarian, Faculty of Law, The University of Westem Ontario.

1. "Charles deserves a chance at throne, poll shows," The London Free Press (London, Ontario), 29 December 1988, at A10.

2. The distinguished British joumalist and author, J.A. Spender, in an article entitled "King and People," published in January 1937, noted: "It was a favourite device of Queen Victoria's to hint at this possibility [abdication] when displeased with her ministers." He gave some examples, (1937) 141 The Fortnightly (n.s.), 1, at 7. Prime Minister Mackenzie King quoted from the article in the Canadian House of Commons on 19 January 1937. See Canada, House of Commons, Debates, 2 nd sess., 18th Parl. (1937), at 69.

3. W.P.M. Kennedy, The Constitution of Canada, 1534-1937, reprint of 2nd ed., 1938 (New York: Russell \& Russell, 1973), at 555-64. The 1938 edition was originally published by Oxford University Press in London.

4. The Statute of Westminster, 1931 (U.K.), 22 \& 23 Geo. 5, c. 4. 
legislation was necessary to give effect to the instrument. ${ }^{5}$ On the very day (December 10, 1936) that His Majesty's Declaration of Abdication Bill was introduced in the House of Commons at Westminster, the Canadian government (technically a committee of the King's Privy Council for Canada), which had been consulted and kept informed of developments, passed an order in council expressing Canada's request for and consent to the bill. ${ }^{6}$ It quickly passed through all the stages in both Houses of the United Kingdom Parliament and received royal assent by royal commission on December 11,1936. The preamble to the Act includes a statement that "the Dominion of Canada pursuant to the provisions of section four of the Statute of Westminster, 1931, has requested and consented to the enactment of this Act." The names of the other consenting Dominions follow. ${ }^{7}$

Although the above procedure adhered to the law as contained in section 4 of the Statute of Westminster, the preamble to that Act includes a statement that "it would be in accord with the established constitutional position of all the members of the Commonwealth in relation to one another that any alteration in the law touching the Succession to the Throne or the Royal Style and Titles shall henceforth require the assent as well of the Parliaments of all the Dominions as of the Parliament of the United Kingdom. "' Since His Majesty's Declaration of Abdication Act affected the succession to the Throne, this seemed to suggest that by convention if not by law, the consent of the Canadian government was not sufficient; the Act should have the assent of the Parliament of Canada, which had not been in session at the time of the abdication. ${ }^{9}$ Therefore, early in 1937, the Canadian Parliament passed an Act declaring as follows: ${ }^{10}$

The alteration of the law touching the succession to the Throne set forth in the Act of Parliament of the United Kingdom intituled "His Majesty's Declaration of Abdication Act, 1936" is hereby assented to.

The texts of the Instrument of Abdication and the United Kingdom's Abdication Act were contained in schedules to the Canadian Act.

Kennedy remarked that the Canadian government "took care with abundance of caution, to satisfy every conceivable jot and tittle of law and convention," adding that he believed the "Canadian action erred on the side of supererogation." Canadian Prime Minister, Mackenzie King, noted during the debate on the bill in the Canadian House of Commons that although the preamble to the Statute of

5. The right of the King to abdicate and the role of Parliament in giving effect to the monarch's abdication were discussed in the Canadian House of Commons on 18 and 19 January 1937. See Canada, House of Commons, Debates, 2nd sess., 18th Parl. (1937), at 42-3 \& 68-9.

6. The full text of the order in council is given in the House of Commons Debates cited above (note 5), at 41.

7. His Majesty's Declaration of Abdication Act, 1936 (U.K.), 1 Edw. 8 \& 1 Geo. 6, c. 3.

8. Supra, note 4.

9. The Canadian order in council, passed on 10 December 1936, noted that Parliament had been summoned to meet on 14 January 1937 and that it was impossible "so to expedite the assembling of the parliament of Canada as to enable appropriate parliamentary action to be taken prior to or contemporaneously with the enactment of the proposed legislation by the parliament at Westminster." See House of Commons Debates cited above (note 5), at 41.

10. An Act respecting alteration in the law touching the Succession to the Throne, S.C. 1937, c. 16. The Act received royal assent on 31 March 1937.

11. Kennedy, supra, note 3 at 562 . 
Westminster was not an operative part of the statute, it was of special significance in relation to the purpose of the statute. ${ }^{12}$

The procedure followed in 1936-37 would not be correct today. Since the passage of the Canada Act, 1982 and the coming into force of the Constitution Act, 1982, no subsequent Act of the United Kingdom Parliament extends to Canada as part of its law..$^{13}$ Moreover, the Constitution Act, 1982, repealed section 4 of the Statute of Westminster as far as it applies to Canada, thus making it doubly clear that the United Kingdom Parliament cannot now legislate for Canada even at the latter's request and with its consent. ${ }^{14}$

An abdication act passed by the United Kingdom Parliament to give effect to the monarch's instrument of abdication would not extend to Canada. Charles III (or whatever name the Prince of Wales took on ascending the Throne) would be King of the United Kingdom of Great Britain and Northem Ireland, but Elizabeth II would still be Queen of Canada. In all probability, arrangements would be made to introduce legislation in the Canadian Parliament at approximately the same time as in the United Kingdom Parliament and perhaps to bring both Acts into force by proclamation on the same date. However, if there was any urgency in the matter, the problem which arose in 1936 (namely, the Canadian government not being in session), could not be resolved now as it was then. There can be no doubt that Canada and the United Kingdom could, in this situation, have different monarchs, in spite of the intent to the contrary expressed in the preamble to the Constitution Act, 1867. ${ }^{15}$

Even more important is the question of whether, under the Constitution Act, 1982, the Parliament of Canada has authority to pass an abdication act. Could it be that this is an amendment to the Constitution of Canada in relation to the office of the Queen and therefore requiring the consent not only of Parliament, but also of all the provincial legislatures? ${ }^{16}$ (One hopes not, for the rigidity of the amending formula would make it very difficult to accomplish). It used to be said that statutes of the Canadian Parliament relating to the succession to the Throne, demise of the Crown, the Governor General, and certain other matters were part of the Constitution. ${ }^{17}$ The abdication of King Edward VIII affected the succession to the

12. House of Commons Debates, at 67-8.

13. Canada Act 1982 (U.K.), 1982, c. 11, s. 2.

14. Constitution Act, 1982 [enacted by Canada Act 1982 (U.K.), 1982, c. 11], s. 53(1) and Schedule, Item 17.

15. Enacted as the British North America Act, 1867 (U.K.), 30 \& 31 Vict. c. 3. In addition to the reference in the preamble to the provinces wishing to be federally united under the Crown of the United Kingdom, the following statement was made in section 2 of the Act: "'The provisions of this Act referring to Her Majesty the Queen extend also to the Heirs and Successors of Her Majesty, Kings and Queens of the United Kingdom of Great Britain and Ireland." However, this section was repealed by the Statute Law Revision Act, 1893 (U.K.), 56 \& 57 Vict. c. 14, s. 1 \& Schedule, because it was considered unnecessary after the enactment of the Interpretation Act, 1889 (U.K.), 52 \& 53 Vict. c. 63, s. 30. which contained a general provision indicating that references to the sovereign reigning at the time of the passing of an Act should "unless the contrary intention appears be constned as referring to the Sovereign for the time being . . ." In relation to the "Constitution of Canada," this does not say quite the same thing as the repealed section 2, but British legislators in 1889 and 1893 could not be expected to foresee the effects of the passage of the Statute of Westminster, 1931, or the Canada Act 1982. No doubt they thought of the British North America Act as an ordinary statute (rather than as a Canadian constitutional document) to which the Interpretation Act of the United Kingdom would apply.

16. Supra, note 14, s. 41(a).

17. See, for instance, Amos J. Peaslee, Constiturions of Nations, rev. 3rd ed., prepared by Dorothy Peaslee Xydis (The Hague: Nijhoff, 1965-70), vol. 4, at 207. 
Throne because he renounced it not only for himself, but also for his descendants. The United Kingdom Abdication Act confirmed that "His Majesty, His issue, if any, and the descendants of that issue, shall not after His Majesty's abdication have any right, title or interest in or to the succession to the Throne." 18 If Elizabeth II were to abdicate, there would be no change in the succession to the Throne because her eldest son, the heir apparent, would succeed. ${ }^{19}$ However, legislation would still be needed to give effect to an instrument of abdication. It would provide, as was the case in 1936, that there would be a demise of the Crown so that the person next in line could succeed to the Throne. Thus, in Canada, if an Act relating to the demise of the Crown is part of the Constitution, an abdication act would appear to be a constitutional amendment. I hasten to add, however, that I do not believe this to be the case.

The Constitution Act, 1982, in defining the "Constitution of Canada" does not list acts relating to such matters as succession to the Throne, demise of the Crown, and the Governor General.$^{20}$ Nor does it list the Supreme Court Act, ${ }^{21}$ although references to the Supreme Court of Canada in ss. 41 (d) and 42 (1)(d) of the Constitution Act, 1982, have raised questions as to the status of the Supreme Court Act. Some constitutional authorities argue that because the word "includes" rather than the word "means" is used in defining the Constitution, the lists in section 52(2) and the Schedule to the Constitution Act, 1982, are not exhaustive..$^{22}$ In my opinion, subsequent events tend to refute the "not exhaustive" theory. For instance, the Governor General's Act was amended in 1985 by ordinary legislative process, ${ }^{23}$ thus implying that it is not part of the Constitution of Canada as defined in the Constitution Act, 1982. If it were, unanimous consent would be required to amend it because it relates to the office of Governor General ${ }^{24}$ It is true that there has been no judicial pronouncement on the constitutionality of that amendment, but the very fact that it has not been challenged in the courts lends support to the theory that the Governor General's Act is not part of the Constitution of Canada. A bill proposing further amendments to the Governor General's Act was introduced in the House of Commons on June 26, 1989:25 at the time of writing, it had not progressed beyond first reading.

18. Supra, note 7 , s. 1(2).

19. Albert, Duke of York, who in 1936 succeeded to the Throne as King George VI, had been heir presumptive, rather than heir apparent; that is, he would have ceased to be heir had Edward VIII married and a child been bom to him before his abdication.

20. For the acts included, see Constitution Act, 1982, s. 52(2) and Schedule.

21. R.S.C. 1970, c. S-19 at the time of the passage of the Constitution Act, 1982; now R.S.C. 1985, c. S-26.

22. For statements of this view, see Stephen A. Scott, "Pussycat, Pussycat or Patriation and the New Constitutional Amendment Processes" (1982), 20 U.W.O. Law Review, 247, at 250, and R.I. Cheffins and P.A. Johnson, The Revised Canadian Constitution: Politics as Law (Toronto: McGraw-Hill Ryerson Limited, 1986), at 17-18 \& 70-76. For the opposing view, see Peter W. Hogg, Constitutional Law of Canada, 2nd ed. (Toronto: The Carswell Company Limited, 1985), at 6-8.

23. An Act to amend the Governor General's Act, the Governor General's Retiring Annuity Act, the Salaries Act and the Judges Act, S.C. 1985, c. 48. Section 1 amends the Governor General's Act and is now cited R.S.C. 1985, c. 50 (1st supp.), s. 1. In R.S.C. 1985, the Governor General's Act and the Governor General's Retiring Annuity Act are combined in one statute called the Governor General's Act. (R.S.C. 1985, c. G-9).

24. Constitution ACt, 1982, s. 41(a). If the Governor General's Act were part of the Constitution of Canada and amendable only under this subsection, there would be a conflict with s. 105 of the Constitution Act, 1867, which allows the Parliament of Canada to alter the Govemor General's salary.

25. Bill C-31, An Act to Amend the Governor General's Act, 2nd sess., 34th Parl. 
The framers of the Meech Lake Constitutional Accord (1987) agreed that certain provisions relating to the composition of the Supreme Court of Canada and the appointment of judges to it should be entrenched in the Constitution. ${ }^{26}$ This seemed to imply that the Supreme Court Act was not part of the Constitution and that only certain provisions relating to the Supreme Court of Canada should be given constitutional status. This theory was strengthened by the enactment by the Parliament of Canada late in 1987 of some amendments to the Supreme Court Act. ${ }^{27}$ There was no attempt here to change provisions in the Supreme Court Act before they were entrenched. The amendments were mainly procedural in nature and related to matters which clearly should not be included in the Constitution.

These developments seem to make it reasonable to conclude that only the acts and orders listed in s. 52(2) of the Constitution Act, 1982, and the Schedule to that Act are to be regarded as part of the Constitution of Canada. If this is so, it seems to follow that there is nothing in the Constitution of Canada that would necessitate a constitutional amendment in the event of the abdication of the monarch. It remains to be determined, however, under what head of power the Parliament of Canada would act in implementing an abdication. Clearly, none of the thirty specific classes of subjects listed in s. 91 of the Constitution Act, 1867, are appropriate. Nor do any of the additional legislative authority conferred on Parliament by the Constitution Acts, 1871 and $1886,{ }^{28}$ or by the Statute of Westminster, relate to succession to the Throne, though the preamble to the last-named Act implies that the Dominion Parliaments have power to enact laws "touching the succession to the Throne" and "the Royal Style and Titles.." It is necessary then to return to s. 91 of the Constitution Act, 1867, remembering that the thirty classes of subjects noted there are not exhaustive, but are listed "for greater Certainty, but not so as to restrict the Generality of the foregoing Terms of this Section." This leads to the conclusion that in implementing an abdication the Parliament of Canada would act under the general power conferred by s. 91 " to make Laws for the Peace, Order, and good Government of Canada" in relation to matters not assigned exclusively to the legislatures of the provinces.

26. Section 6 of the proposed Constitution Amendment would add new sections 101A-101E relating to the Supreme Court of Canada at the end ot "Part VII, Judicature" of the Constitution Act, 1867.

27. An Act to amend the Supreme Courn Act and to amend various other Acts in consequence thereof, S.C. 1987 , c. 42 ; now R.S.C. 1985 , c. 34 (3rd supp.). The first seven sections amend the Supreme Court Act.

28. Enacted as British North America Act, 1871 (U.K.), 34 \& 35 Vict., c. 28, and British North America Act, 1886 (U.K.), 49 \& 50 Vict., c. 35. 